\title{
Temperature Conditioning and Surface Treatments of Grapefruit Affect Expression of Chilling Injury and Gas Diffusion
}

\author{
Roy E. McDonald, T. Gregory McCollum, and Harold E. Nordby \\ United States Department of Agriculture, Agricultural Research Service, U.S. Horticultural Research \\ Laboratory, 2120 Camden Road, Orlando, FL 32803 \\ Additional index words. Citrus paradisi. weight loss, postharvest, squalene, squalane, safflower oil, Flavorseal
}

\begin{abstract}
Marsh' Grapefruit (Citrus paradisi Macf.) were temperature conditioned (7 days at 15C), wiped with hexane, treated with squalene, squalane, or safflower oil (all $10 \%$ in hexane), or waxed with a commercial fruit wax (Flavorseal) to determine their effects on weight loss, chilling injury $(\mathrm{Cl})$ symptoms on the peel, and gas exchange. Following 3 weeks of storage at SC, wiping fruit with hexane resulted in a significant decrease in weight loss, but not CI. Temperature conditioning and Flavorseal independently inhibited weight loss and Cl development. Squalene inhibited CI development, but not weight loss. Chilling injury on fruit treated with squalene or Flavorseal was similar in appearance, but significantly less common than that on nontreated fruit. Grapefruit peel accounted for $92 \%$ of the gas diffusion of fruit, and resistance coefficients for peel and whole fruit were similar. Less ethane diffused into fruit that were: temperature-conditioned compared with nonconditioned, hexane wiped compared with nonhexane-wiped, and squalene-treated compared with nonsqualene treated fruit. Ethane influx was significantly restricted into squalane- and squalane-treated fruit compared with Flavorseal- or safflower oil-treated fruit. Oxygen and $\mathrm{CO}_{2}$ influx was significantly reduced by Flavorseal, safflower oil, squalene, and squalane. Squalane was the most restrictive of ethylene efflux followed by safflower oil, squalene, and Flavorseal. All of these surface treatments are known to reduce CI on grapefruit. These data indicate that water loss is less important to the development of $\mathrm{Cl}$ than has been previously suggested, and that the beneficial effects of squalene are not the result of an inhibition of water loss. Permeability of grapefruit peel to gases other than $\mathrm{H}_{2} \mathrm{O}$ vapor may also influence the expression of $\mathrm{Cl}$.
\end{abstract}

Grapefruit, like many other tropical and subtropical fruits, develop chilling injury (CI) when stored at temperatures $<10$ to 12C (Chace et al., 1966; Grierson, 1974; Pantastico et al., 1968). High-temperature prestorage conditioning or curing treatments have been successful in preventing or reducing $\mathrm{CI}$ in many horticultural crops (Wang, 1990). Although temperature conditioning has been shown to reduce CI in many fruits and vegetables, little is known about its mode of action. Reports describe physical changes to the product as a result of temperature conditioning. The only research relating biochemical changes and the reduction of $\mathrm{CI}$ by temperature conditioning were polyamine chanes in lemon [ (Citrus limon (L.) Burm.] (McDonald, 1986) and squash ( Cucurbita pepo L.) (Kramer and Wang, 1990; McCollum et al., 1991) and lipid components of the epicuticular wax of grapefruit (Nordby and McDonald, 1990b. 1991).

It is generally accepted that conditions and treatments that reduce weight loss will reduce the incidence of CI (Wang, 1990). Raising the relative humidity to $100 \%$ reduced CI in limes and grapefruit (Pantastico et al., 1968). Moisture loss has been implicated as a causal factor in the CI of cucumber and pepper (Capsicum annuum L.) (Morris and Platenius, 1939). Purvis (1984) concluded that moisture loss during low-temperature storage of grapefruit was a contributing factor to CI symptom development.

Waxing has often been reported to decrease the expression of $\mathrm{Cl}$ in grapefruit (Forney and Lipton, 1990) and to alter gas exchange

Received for publication 22 May 1992. Accepted for publication 14 Nov. 1992. We thank Roxanne Wiseman for competent technical assistance during the course of this work. Mention of a trademark, warranty, proprietary product, or vendor does not constitute a guarantee by the U.S. Dept. of Agriculture and does not imply its approval to the exclusion of other products or vendors that may also be suitable. The cost of publishing this paper was defrayed in part by the payment of page charges. Under postal regulations, this paper therefore must be hereby marked advertisement solely to indicate this fact. between the fruit and its environment (Hagenmaier and Shaw, 1992). The effects of waxing on reducing CI may be related to the waxing effect on permeability to $\mathrm{O}_{2}, \mathrm{CO}_{2}$, ethylene, or water vapor.

Nordby and McDonald (1990b) reported that squalene reduces CI on grapefruit, but like temperature conditioning, its mode of action is unknown. Squalane also was reported to reduce CI of grapefruit (Nordby and McDonald, 1990a). Safflower oil reduced CI ofgrapefruit (Aljuburi, 1982), but had no effect on CI symptom development on lemon (McDonald, 1986).

Thus, temperature conditioning and squalene or squalane may act in a physical manner (i.e., by increasing resistance to gas exchange) to reduce CI. Therefore, experiments were conducted to determine the effects of temperature conditioning, waxing, wiping with hexane, and squalene on weight loss. CI expression on the peel, and gas exchange in grapefruit. Because squalane and safflower oil also have been reported to reduce CI, the effects of these compounds and Flavorseal and hexane wiping on gas exchange were also determined. Ethane was used to measure the effectiveness of treatments as diffusion barriers because it is a nonrespiratory gas that provides a quantitative approach to the diffusion of ethylene and other gases in plant tissues.

\section{Materials and Methods}

Weight loss and chilling injury. Two experiments were conducted to determine the effects of temperature conditioning, wiping with hexane, or squalene on weight loss and CI. Freshly harvested 'Marsh' grapefruit were obtained from a commercial grove near Merritt Island, Fla., for three separate tests (replications) in October. On each occasion, 40-count fruit $(10 \pm 1.3 \mathrm{~cm}$ in diameter) were degreened with ethylene at $\approx 5 \mu \mathrm{l} \cdot \operatorname{liter}^{-1}[30 \mathrm{C}, 90 \%$

Abbreviations: CI, chilling injury; R, resistance. 
$\pm 2 \%$ relative humidity $(\mathrm{RH})]$ for $72 \mathrm{~h}$. Following degreening, the fruit were washed with a nonfungicidal soap (Mold Strip 25; Fresh Mark Chemical, Ocoee, Fla.), surface-dried, and randomized into eight 40-fruit lots to test the effects of temperature conditioning, wiping with hexane, and squalene. In the hexane treatment, fruit were wiped for $15 \mathrm{sec}$ with a paper towel soaked in hexane. Squalene $[10 \%(w / v)$ in hexane] was applied with a chromatographic sprayer to give $\approx 15 \mathrm{mg} / 100 \mathrm{~cm}^{2}$ per fruit. Four lots were stored 3 weeks at $5 \mathrm{C}$ and $86 \% \pm 5 \% \mathrm{RH}$, and four lots were temperature conditioned for 1 week at $15 \mathrm{C}$ and $90 \% \pm 2 \% \mathrm{RH}$ before 3 weeks of storage at $5 \mathrm{C}$.

Weight loss for temperature-conditioned fruit was the weight difference between the start of conditioning and after 3 weeks of storage at $5 \mathrm{C}$, whereas weight loss for nonconditioned fruit was the difference in weight between 0 and 3 weeks of storage at 5C. Ten fruit were weighed individually to determine weight loss in each treatment. Following storage, the fruit were evaluated for visible symptoms of CI, i.e., pitting and rind scald. Fruit were classified into one of five CI categories, depending on the surface area affected, where $1=0 \%, 3=$ below $5 \%, 5=5 \%$ to $25 \%, 7=26 \%$ to $50 \%$, and $9=$ more than $50 \%$. A CI index was calculated by summing the products of the number of fruit in each category by the value of each category and then dividing this sum by the total number of fruit evaluated. Data for weight loss and CI were analyzed as a randomized block design with factorial treatments $[( \pm)$ temperature conditioning $X( \pm)$ wiping with hexane $X( \pm)$ squalene)] with three harvests (blocks) using the SAS analysis of variance (ANOVA) procedure (SAS Institute, 1988).

A $2 \times 3$ factorial experiment was conducted to compare the effects of temperature conditioning with squalene, a commercial wax (Flavorseal, FMC Corp., Lakeland, Fla.) applied with a commercial fruit waxer, and no surface treatment on weight loss and CI. Fruit were obtained, degreened, and washed as described above.

Resistance of fruit to gas diffusion. First-order rate constants and resistance coefficients for the diffusion of ethane through whole fruit, peel, and stem scar of grapefruit were determined according to Cameron and Yang (1982). Gas permeabilities of tomato (Lycopersicum esculentum Mill. cv. Sunny), obtained from a local market, were determined to verify if our results gave results similar to those of Cameron and Yang (1982). 'Marsh' grapefruit were harvested from trees in June. Individual fruit were placed in desiccators with a constant flow $\left(500 \mathrm{ml} \cdot \mathrm{min}^{-1}\right)$ of air containing ethane at $900 \mu \mathrm{l} \cdot$ liter $^{-1}$ and kept for $3 \mathrm{~h}$ to attain fruit equilibrium.

Ethane influx. Freshly harvested 'Marsh' grapefruit were obtained from a commercial grove near Merritt Island, Fla., in March to determine the effects of temperature conditioning, wiping with hexane, and squalene on diffusion of ethane through their peels. Fruit were prepared for treatments the same as for the weight loss and $\mathrm{Cl}$ experiments, except that degreening was not necessary. Individual fruit were placed in 1750-m] glass jars and purged with a constant flow $\left(500 \mathrm{ml} \cdot \mathrm{min}^{-1}\right)$ of air containing ethane at 900 $\mu \mathrm{l} \cdot \operatorname{liter}^{-1}$ (Saltveit and Dilley, 1977) for exactly $90 \mathrm{~min}$. Fruit were then submersed in water and a partial vacuum applied to extract the internal gases (Beyer and Morgan, 1970); ethane analyses were conducted by standard gas chromatography methods. Statistical analysis was the same as for the weight loss and CI experiments.

In another experiment, safflower oil, squalene, or squalane (each $10 \%(\mathrm{w} / \mathrm{v})$ in hexane], were applied with a chromatographic sprayer. Flavorseal was applied as stated above. A hexane spray was also included as a treatment. Ethane influx rates were determined as described above, 1 day after application and following 4 weeks of storage at $10 \mathrm{C}$ and $86 \% \pm 5 \% \mathrm{RH}$ to determine if the treatments were effective over time. The data were analyzed as a completely randomized design with four single-fruit replications.

Oxygen influx. Saffloweroil, squalene, squalane, and Flavorsea1 were applied as described above to 'Marsh' grapefruit harvested in March. Oxygen influx was determined at $\approx 24 \mathrm{C} 1$ day after application and following 4 weeks of storage at $10 \mathrm{C}$ and $86 \% \pm 5 \% \mathrm{RH}$. Individual fruit were placed into glass jars and purged with a constant flow $\left(500 \mathrm{ml} \cdot \mathrm{min}^{-1}\right)$ of $99.8 \% \mathrm{O}_{2}$ for exactly $7 \mathrm{~min}$. The fruit were then submersed in water as described above, and an internal gas sample was analyzed for $\mathrm{O}_{2}$ by standard gas chromatographic methods. Because initial $\mathrm{O}_{2}$ concentrations depended on individual surface treatments, $\mathrm{O}_{2}$ influx values obtained were normalized by subtraction of initial $\mathrm{O}_{2}$ concentrations. Initial concentrations were determined by analyzing similarly treated fruit before $\mathrm{O}_{2}$ influx. Resulting data were analyzed as a completely randomized design with four single-fruit replications.

Carbon dioxide influx. Surface treatments were applied, fruit were handled, and data analyzed as described above for $\mathrm{O}_{2}$ influx determinations, with the exception that the fruit were subjected to an atmosphere of $40 \% \quad \mathrm{CO}_{2}$ and $10 \% \quad \mathrm{O}_{2}$ at $24 \mathrm{C}$ for exactly $15 \mathrm{~min}$. Carbon dioxide influx values obtained were normalized by subtraction of initial $\mathrm{CO}$, concentrations.

Ethylene efllux. 'Marsh' grapefruit, which had been stored at SC for 9 weeks, beginning in mid-January, to induce CI and ethylene production (McCollum and McDonald, 1992), were warmed in 20C air. Safflower oil, squalene, and squalane [all 10\% (w/v) in hexane] were applied with a chromatographic sprayer and the commercial wax, Flavorseal, was applied as above for studying ethylene accumulation in grapefruit. The calyxes on fruit were removed, stopcock grease was applied to the stem scars, and gas chromatograph septums were placed on top of the grease. After 18 $\mathrm{h}$ at $20 \mathrm{C}, \approx 5 \mathrm{ml}$ internal gas samples were removed through the septums with a $10-\mathrm{ml}$ syringe. A syringe was then used to obtain a 1-ml sample, and ethylene analyses were conducted using standard gas chromatographic procedures. The experiment was a completely randomized design with four single-fruit replications.

\section{Results and Discussion}

Weight loss and chilling injury. Following 3 weeks of storage at $5 \mathrm{C}$, weight loss and CI were significantly inhibited in temperature-conditioned compared with nonconditioned fruit (Table 1, Figs. 1 and 2). Wiping with hexane resulted in a significant decrease in weight loss, but not CI. Squalene significantly inhibited CI, but not weight loss when compared with nontreated fruit. Temperature conditioning may decrease CI by inhibiting water loss. Purvis (1984) concluded that moisture loss during lowtemperature storage of grapefruit appeared to be a contributing factor to CI symptom development. However, squalene reduced CI without reducing weight loss, and wiping with hexane had the unexpected effect of decreasing weight loss, hut had no effect on CI development. Albrigo (1972) and Schulman and Monselise (1970) found that removal of the natural wax from citrus fruits increased water loss. However, both studies used wax-removal procedures that were much harsher than that used in this study. Analysis of the epicuticular wax remaining on the grapefruit after the hexane wiping treatment revealed that about one-fourth of the wax was removed (data not shown). The hexane wiping removed the major portion of the wax alkanes, a substantial amount of the long chain aldehydes $\mathrm{C}_{23}-\mathrm{C}_{34}$, and a small amount of the various terpenoids (data not shown). Wiping with hexane may have redistributed the remaining wax on fruit surfaces to effectively block water vapor diffusion. The role that water loss plays in the 
Table 1. Analysis of variance of a $2 \times 2 \times 2$ factorial experiment examining temperature conditioning, wiping with hexane, and squalene coating on weight loss, chilling injury, and ethane influx into 'Marsh' grapefruit after 3 weeks at $5 \mathrm{C}$ and $86 \% \pm 5 \% \mathrm{RH}$.

\begin{tabular}{|c|c|c|c|c|}
\hline \multirow[b]{2}{*}{ Source } & \multirow[b]{2}{*}{$\mathrm{df}$} & \multicolumn{3}{|c|}{ Mean squares } \\
\hline & & $\begin{array}{l}\mathrm{Wt} \\
\text { loss }\end{array}$ & $\begin{array}{c}\text { Chilling } \\
\text { injury index }\end{array}$ & $\begin{array}{l}\text { Ethane } \\
\text { influx }\end{array}$ \\
\hline Replication & 2 & 0.08 & 0.37 & 129 \\
\hline Conditioning (C) & 1 & $1.88^{\cdots}$ & $5.95^{\circ}$ & $1,725^{*}$ \\
\hline Wiping (W) & 1 & $1.79^{* *}$ & 1.47 & $871^{\circ}$ \\
\hline Squalene (S) & 1 & 0.01 & $3.72^{\circ *}$ & 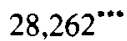 \\
\hline $\mathrm{C} \times \mathrm{W}$ & 1 & 0.01 & 0.78 & $675^{\circ}$ \\
\hline $\mathrm{C} \times \mathrm{S}$ & 1 & 0.02 & $5.85^{* *}$ & $1,023^{*}$ \\
\hline $\mathrm{W} \times \mathrm{S}$ & 1 & 0.15 & 0.21 & 371 \\
\hline $\mathrm{C} \times \mathrm{W} \times \mathrm{S}$ & 1 & 0.01 & 1.14 & $693^{\circ}$ \\
\hline Error & 14 & 0.04 & 0.41 & 2,623 \\
\hline
\end{tabular}

development of CI symptoms is not clear from these data, but the beneficial effects of squalene appear not to be the result of an inhibition of water loss.

Weight loss was significantly reduced by Flavorseal wax compared with the squalene treatment, but absolute values among the treatments were similar (Table 2). However, Flavorseal wax and squalene were equally effective in reducing CI. The effects of temperature conditioning and Flavorseal wax or squalene application were not synergistic (no interaction detected). Although Flavorseal wax may have been expected to decrease weight loss and $\mathrm{CI}$, this is the first report of temperature conditioning reducing weight loss, and its ability to reduce CI may be related to gas exchange in the fruit. The temperature-conditioned fruit lost less weight even though they were kept longer. Total holding time for temperature-conditioned fruit was 4 weeks ( 1 week at $15 \mathrm{C}+3$ weeks at 5C) compared with 3 weeks (5C) for nontemperatureconditioned fruit. Therefore, while temperature conditioning appears to affect CI through permeability of water vapor, squalene acts in a different but unknown manner.

Resistance of fruit to gas diffusion. Cameron and Yang (I 982) reported that $\approx 97 \%$ of gas exchange of a tomato fruit occurs through the stem scar, with the remainder occurring through the

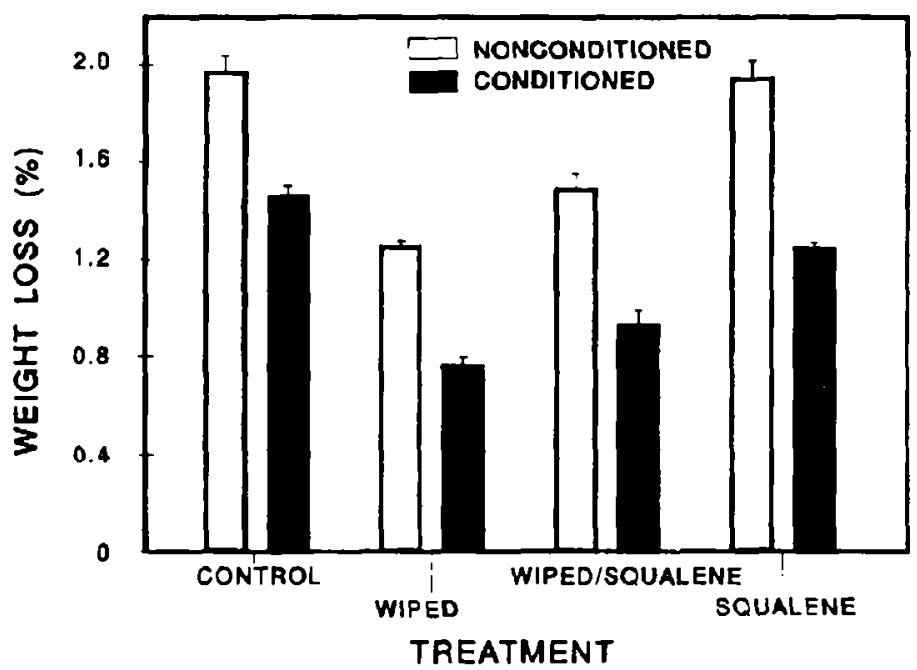

Fig. 1. Effect of temperature conditioning, wiping with hexane, and squalene on weight loss in 'Marsh' grapefruit stored for 3 weeks at 5C. Vertical bars represent SE of the means. skin. Using their methodology, we found that first-order rate constants for grapefruit peel and whole fruit were similar, as well as constants for tomato stem scars and whole fruit (Table 3). Most ( $92 \%)$ of the diffusion of gases occurred through the peel of grapefruit, whereas most $(92 \%)$ of the diffusion of gases took place through the stem scar of tomatoes. Resistance of grapefruit peel to gas diffusion was $\approx 75$-fold less compared with tomato skin, although the resistance coefficients $(\mathrm{R})$ of grapefruit and tomato stem scars were similar. The resistance coefficient of grapefruit stem scars is less important to whole fruit gas exchange because only $-0.3 \%$ of a grapefruit peel surface is stem scar, whereas $3.8 \%$ of a tomato fruit surface is stem scar.

To decrease gas exchange in tomato, it would be necessary to block the stem scar. However, to decrease gas exchange of a grapefruit. it would be more important to reduce the permeability of the peel. This conclusion indicates that treatments that decrease the permeability of grapefruit peel to gas diffusion, as squalene or temperature conditioning do, could play a role in reducing CI.

Ethane influx. It was not possible to apply a surface treatment such as squalene before "loading" the fruit with a noncondensable gas, such as ethane, to determine resistance coefficients because the restrictive nature of the treatment prevented it. It was possible, however, to develop influx values for ethane and respiratory gases to study the effects of treatments as diffusion barriers.

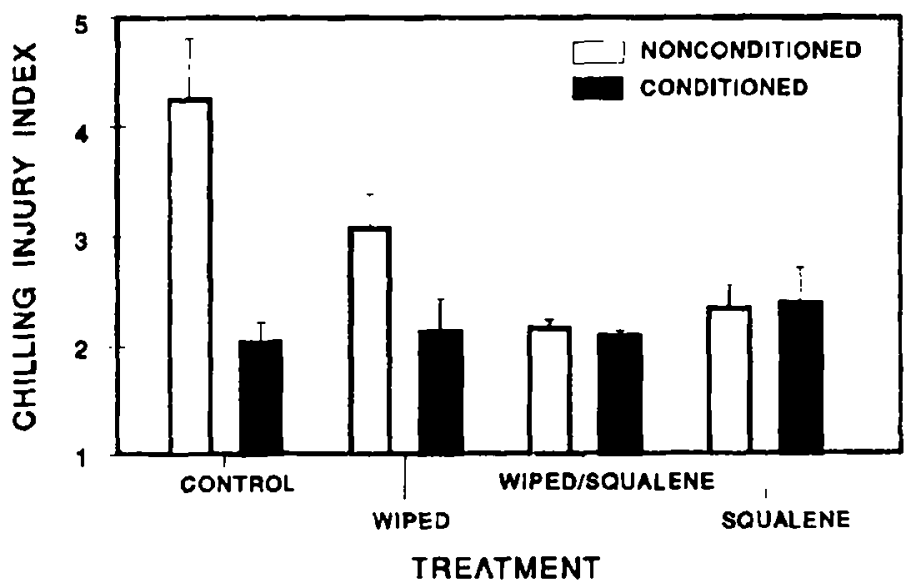

Fig. 2. Effect of temperature conditioning, wiping with hexane, and squalene on chilling injury on 'Marsh' grapefnuit stored for 3 weeks at $5 \mathrm{C}$. Vertical bars represent SE of the means. 
Table 2. Effects of surface treatments on weight loss and chilling injury of 'Marsh' grapefruit after 3 weeks of storage at $5 \mathrm{C}$ and $86 \% \pm 5 \% \mathrm{RH}$.

\begin{tabular}{|c|c|c|c|}
\hline $\begin{array}{l}\text { Surface } \\
\text { treatment }\end{array}$ & & $\begin{array}{c}\mathrm{W} t \text { loss } \\
(\%)^{2}\end{array}$ & $\begin{array}{l}\text { Chilling } \\
\text { injury index }\end{array}$ \\
\hline None & & $1.0 \mathrm{a}$ & $2.0 \mathrm{a}$ \\
\hline Flavorseal wax & & $\mathrm{Cl} .7 \mathrm{~b}$ & $1.3 \mathrm{~b}$ \\
\hline \multirow[t]{3}{*}{ Squalene } & & $1.2 \mathrm{a}$ & $1.4 \mathrm{~b}$ \\
\hline & & \multicolumn{2}{|c|}{ Mean squares } \\
\hline & & $\mathrm{N}_{\mathrm{t}}$ & Chilling \\
\hline Source & df & loss & injury index \\
\hline Replication & 2 & $\overline{0.1} \overline{2}$ & 0.01 \\
\hline Conditioning (C) & 1 & $0.134^{\cdots}$ & $1.33^{\circ}$ \\
\hline Treatment (T) & 2 & $0.144^{*}$ & $0.85^{\circ}$ \\
\hline $\mathrm{C} \times \mathrm{T}$ & 2 & $0.1) 4$ & 0.49 \\
\hline Error & 10 & 0.134 & 0.19 \\
\hline
\end{tabular}

¿alues in a column followed by different lett ers are different at $P=0.05$.

${ }^{* * * * * * *}$ Significant at $P=0.05,0.01$, or 0.001 , 1.espectively.

Ethane influx was significantly greater in fruit that were: nonconditioned compared with temperature-conditioned, nonhexane-wiped compared with hexane-wiped, and nonsqualenetreatedcompared with squalene-treated (Fig. 3, Table 1). Although temperature conditioning and wiping with hexane had an effect on reducing the permeability of grapefruit peel to ethane, the effect of squalene was much greater. Temperature conditioning increased $\mathrm{R}$ by $>3$-fold and squalene increased it by $\approx 19$-fold (data not shown). Wiping with hexane had no effect on R. Apparently, applying squalene to the surface of fruit creates a barrier that effectively reduces the permeability of the peel to ethane.

The amount of ethane that diffused into grapefruit treated with various surface coatings is expressed as a percentage of ethane in the "loading" atmosphere (900 $\left.\mu \mathrm{l} \cdot \mathrm{liter}^{-1}\right)$, in Fig. 4. One day following application, control, hexane spray, and Flavorsealtreated fruit had the least resistance (highest percentage) to ethane influx (Fig. 4A). However, ethane influx was significantly restricted by safflower oil, squalene, and squalane.

Ethane influx was slower in all treatments following4 weeks of

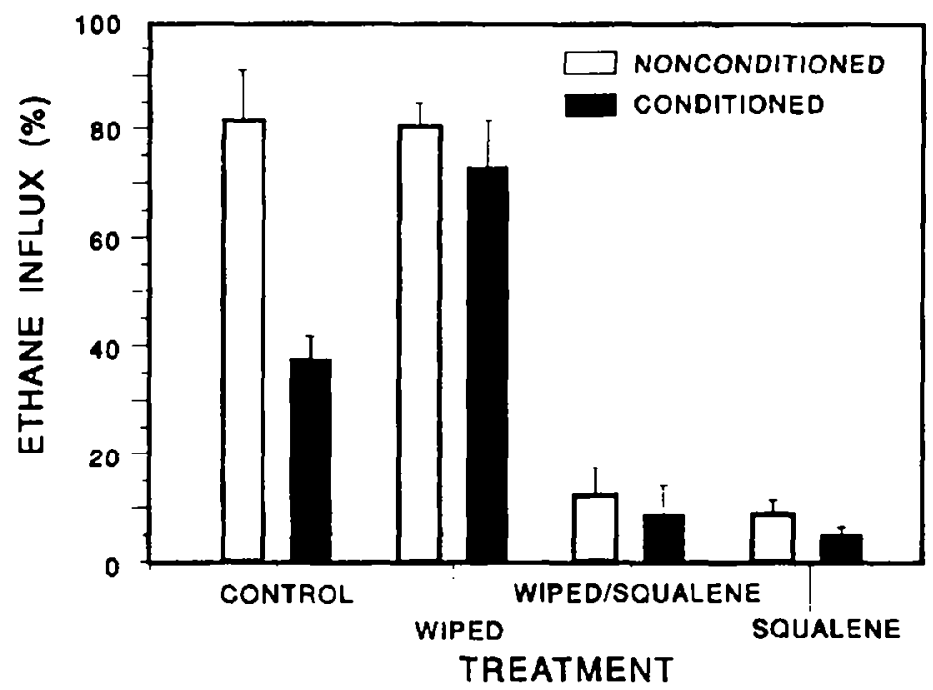

Fig. 3. Effect of temperature conditioning, wiping with hexane, and squalene on ethane influx of 'Marsh' grapefruit stored for 3 weeks at $5 C$. Vertical bars represent SE of the means. storage at 10C (Fig. 4B) compared with determinations made 1 day following application (Fig. 4A). Squalene, safflower oil, and squalane had significantly higher resistance to ethane influx than Flavorseal, hexane spray, and control fruit (Fig. 4B).

Oxygen influx. Safflower oil, squalene, squalane, and Flavorseal significantly increased resistance to $\mathrm{O}_{2}$ influx compared with nonconditioned and hexane spray-treated fruit 1 day following

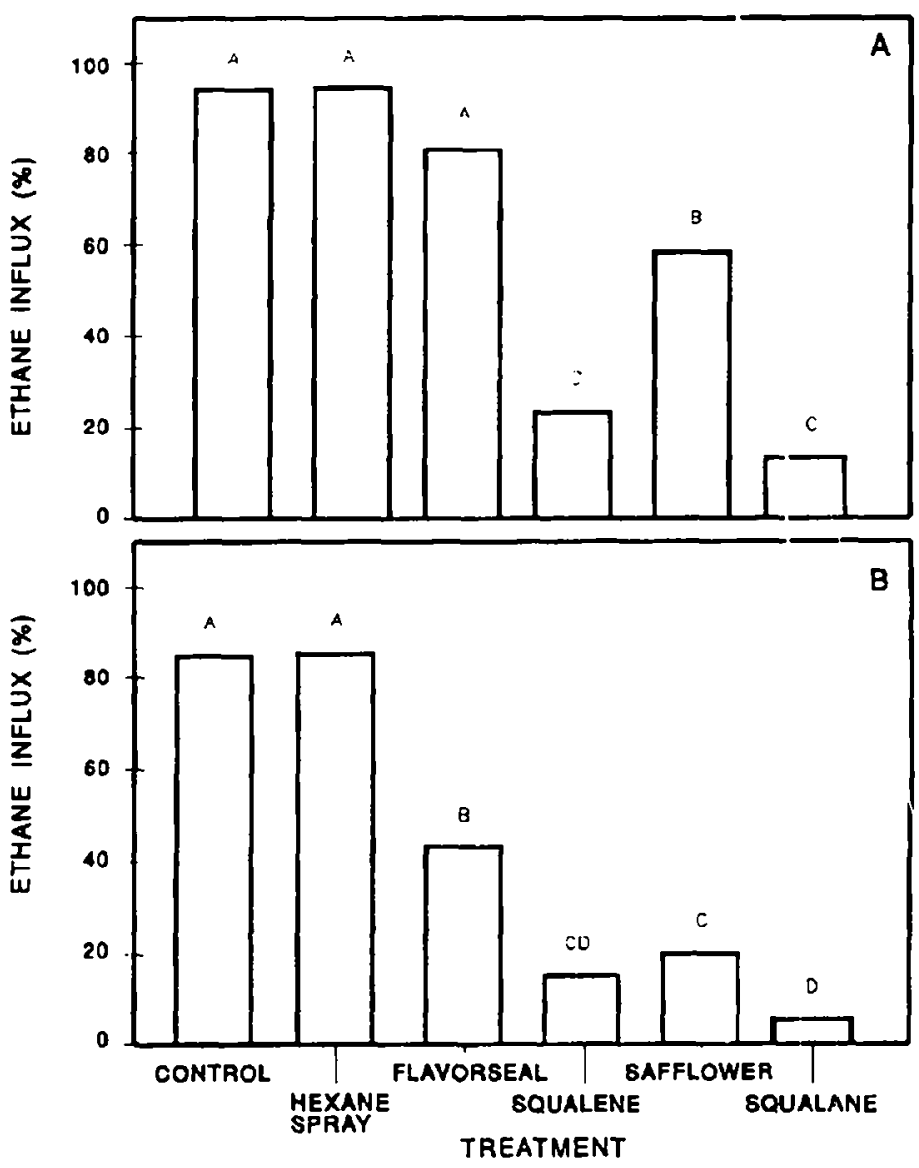

Fig. 4. Effect of surface treatments on ethane influx of 'Marsh' grapefruit 1 day following treatment $(\mathbf{A})$ and after 4 weeks at $10 \mathrm{C}(\mathbf{B})$. Letters indicate mean separation by Duncan's multiple range test, $P=0.05$. 
Table 3. Diffusion of ethane through grapefruit and tomato fruits.

\begin{tabular}{lccc}
\hline Fruit & $\begin{array}{c}\mathrm{K}^{\mathbf{2}} \\
\left(\mathrm{s}^{-1} \times 10^{-5}\right)\end{array}$ & $\begin{array}{c}\text { Diffusion } \\
\text { contribution }\end{array}$ & $\begin{array}{c}\mathrm{R} \\
\left(\mathrm{s} \times \mathrm{cm}^{-1} \times 10^{3}\right)\end{array}$ \\
\hline Grapefruit & 118.6 & 91.7 & 2.2 \\
Peel & 10.8 & 8.3 & 0.2 \\
Stem scar & 129.4 & 100 & 2.2 \\
Whole fruit & & & \\
Tomato & 5.8 & 7.7 & 164.6 \\
Skin & 69.6 & 92.3 & 0.5 \\
Stem scar & 75.4 & 100 & 12.5 \\
Whole fruit & & & \\
\hline
\end{tabular}

${ }^{2}$ Fruit-order rate constants $(\mathrm{k})$ for stem scars wet $\bar{e}$ calculated by subtraction.

yPercent diffusion contribution and resistance cciefficients $(R)$ were calculated from $k$.

application (Fig. 5). Although safflower oil was as effective as Flavorseal, squalene, and squalane initially, the latter three compounds were significantly better than the oil at increasing resistance to $\mathrm{O}_{2}$ influx following 4 weeks of storage at 10C. As was the case with ethane influx, $\mathrm{O}_{2}$ influx was also reduced over time regardless of surface treatment. The increase in resistance to gaseous diffusion in all treatments and controls may have been due to peel dehydration during storage (Ben-Yehoshua, 1967, 1969).

Carbon dioxide influx. It was not possible to "load" grapefruit previously treated with various surface coatings with similar
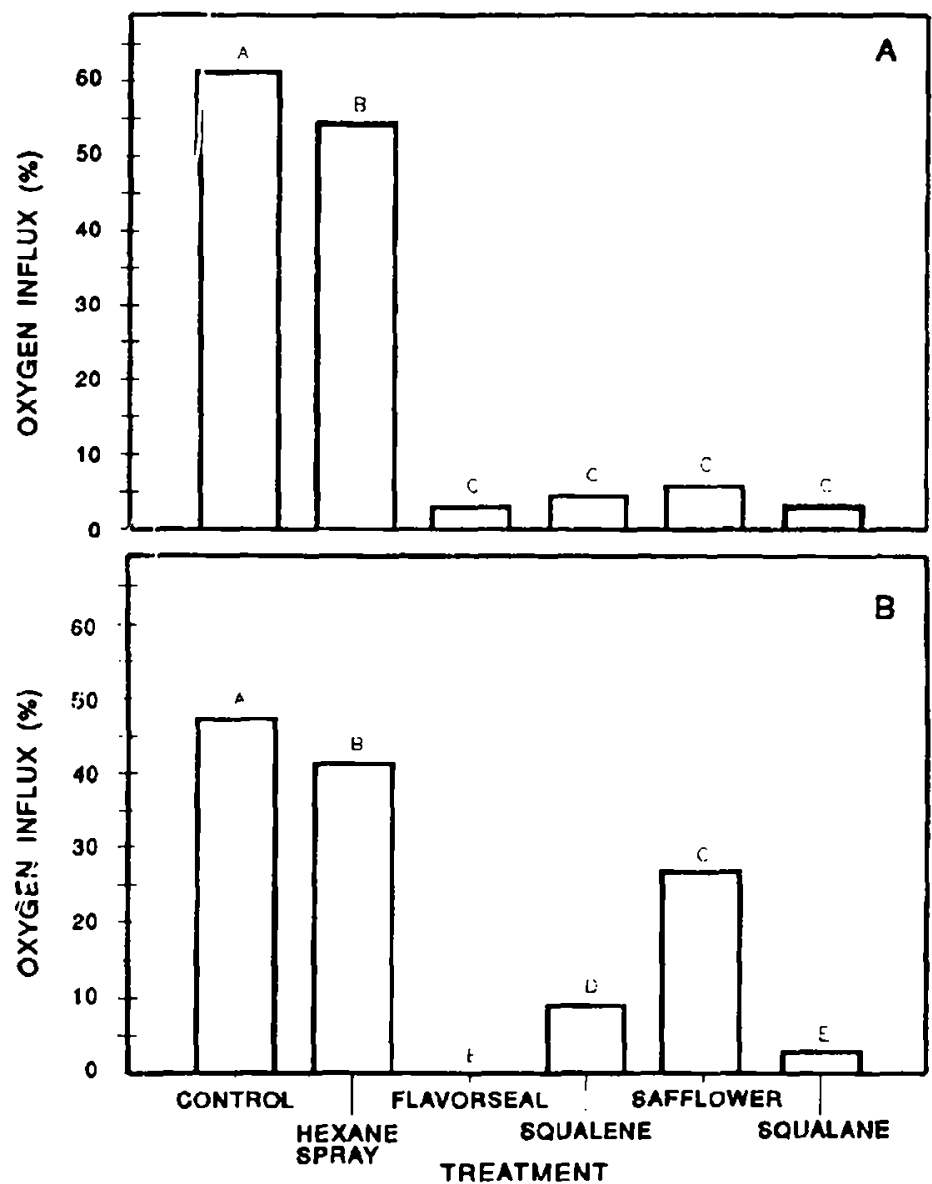

Fig. 5. Effect of surface treatments on $O$, influx of 'Marsh' grapefruit 1 day following treatment $(\mathbf{A})$ and after 4 weeks as $10 \mathrm{C}(\mathbf{B})$. Letters indicate mean separation by Duncan's multiple range test, $P=0.05$. amounts of $\mathrm{CO}_{2}$ to study $\mathrm{CO}_{2}$ efflux. Therefore, $\mathrm{CO}_{2}$ influx was considered as a measure of resistance to $\mathrm{CO}_{2}$ diffusion.

Resistance to $\mathrm{CO}_{2}$ influx was significantly increased by Flavorseal, safflower oil, squalene, and squalane initially, and after 4 weeks of storage at 10C (Fig. 6). Squalene and squalane significantly increased resistance to $\mathrm{CO}_{2}$ influx, both initially and following storage, compared with Flavorseal and safflower oil.

In general, the surface treatments increased the $\mathrm{CO}_{2}$ content and decreased the $\mathrm{O}_{2}$ content of the internal atmosphere of grapefruit. 'The degree of change depended upon the coating used and the

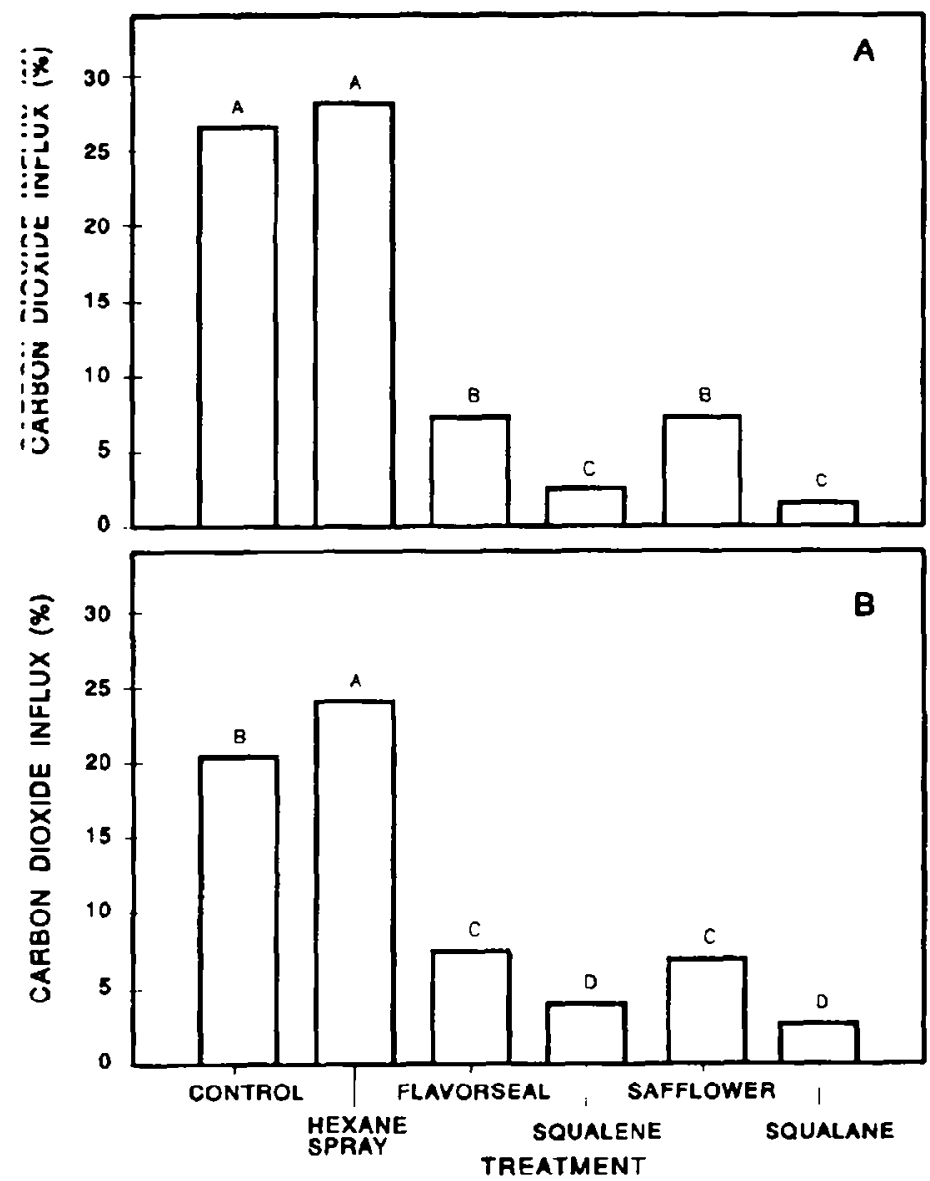

Fig. 6. Effect of surface treatments on $\mathrm{CO}_{2}$ influx of 'Marsh' grapefruit 1 day following treatment $(\mathbf{A})$ and after 4 wecks at $10 \mathrm{C}(\mathbf{B})$. Letters indicate mean :separation by Duncan's multiple range test, $P=0.05$. 
Table 4. Effect of surface treatments on the resistance of 'Marsh' grapefruit to ethane, $\mathrm{O}_{2}$, and $\mathrm{CO}_{2}$

\begin{tabular}{lcccccc}
\hline & \multicolumn{5}{c}{ Resistance $^{2}\left(\mathrm{~s} \times \mathrm{cm}^{-1} \times 10^{3}\right)$} \\
\cline { 2 - 7 } Gas & Control & $\begin{array}{c}\text { Hexane } \\
\text { spray }\end{array}$ & Flavorscal & Squalene & $\begin{array}{c}\text { Safflower } \\
\text { oil }\end{array}$ & Squalane \\
\hline Ethane & 5.9 & 5.8 & 10.1 & 62.5 & 19.1 & 115.0 \\
$\mathrm{O}_{2}$ & 1.4 & 1.7 & 45.0 & 29.0 & 21.9 & 42.8 \\
$\mathrm{CO}_{2}$ & 2.6 & 2.3 & 14.1 & 43.6 & 14.1 & 72.1 \\
\hline
\end{tabular}

${ }^{2}$ Computations based on data in panel $A$ of Figs. 4,5 , and 6 assuming that the fruit were uniform in internal volumes and surface areas.

length of storage. These results support earlier work with oranges [ Citrus sinensis (L.) Osb.] where the degree of change depended upon the wax used (Davis et al., 1967; Eaks and Ludi, 1960).

Ethylene efflux. Treatment of grapefruit with squalane, safflower oil, or squalene resulted in considerably greater ethylene retention than treatment with Flavorseal, sprayed with hexane, or none of them (control) (Fig. 7). The flavedo and the outer cuticle of orange fruit were found to be important structures in directing the diffusion of endogenously produced ethylene, thereby increasing ethylene accumulation in the fruit (Barmore and Biggs, 1972). Thus, the surface treatments used in this study, particularly squalane, safflower oil, and squalene, effectively enhanced the outer peel in further reducing diffusion of endogenously produced ethylene.

Generally, the order of effectiveness of the surface coatings as barriers to gas diffusion in this study was squalane > squalene 2 safflower oil > Flavorseal. Squalane is a completely saturated hydrocarbon; safflower oil is intermediate in saturation; squalene is a highly unsaturated hydrocarbon; and Flavorseal wax is composed of a mixture of aliphatic and aromatic hydrocarbons. Because squalane and squalene differ only in their degree of saturation, it appears that more highly saturated molecules make more effective diffusion barriers.

The effect of the surface treatments on the resistance of grapefruit to ethane, $\mathrm{O}_{2}$, and $\mathrm{CO}_{2}$ is presented in Table 4. These computations are based on data in Figs. 4-6. Waxing with Flavorseal and the coatings of safflower oil, squalene, and squalane all increased the resistance to the noncondensable gases. The latter two compounds were more effective as gas diffusion barriers than the former two. Waxing and sealing citrus fruit in plastic films has been reported by Ben-Yehoshua et al. (1985) to increase their

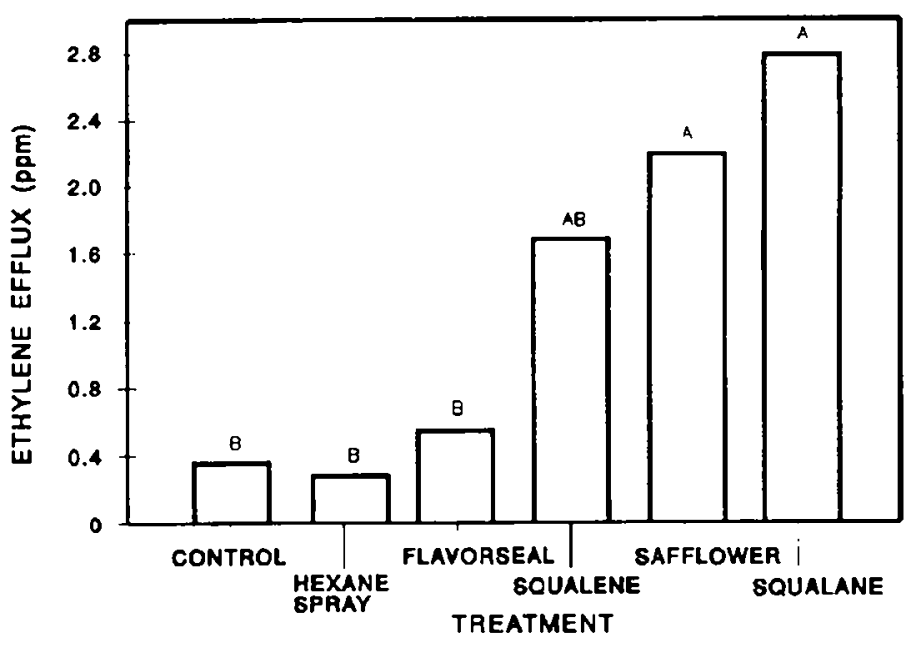

Fig. 7. Effect of surface treatments on ethylene efflux of 'Marsh' grapefruit. Letters indicate mean separation by Duncan's multiple range test, $P=0.05$. resistance to ethylene, $\mathrm{CO}_{2}$, and $\mathrm{O}_{2}$ diffusion.

Since squalene was shown to decrease CI without reducing moisture loss, it may be that the beneficial effects of squalene and squalane, and, to some extent safflower oil, are due to the creation of a barrier that hinders $\mathrm{O}_{2}$ and $\mathrm{CO}_{2}$ diffusion. The effectiveness of modified atmospheres in reducing $\mathrm{CI}$ varies with commodity, $\mathrm{O}$ and $\mathrm{CO}_{2}$ concentrations, and storage temperature (Wang, 1982). Beneficial effects of low $\mathrm{O}_{2}$ and high $\mathrm{CO}_{2}$ to reduce the development of CI in zucchini squash have been reported (Mencarelli et al., 1983: Mencarelli, 1987; Wang and Ji, 1989). Spalding and Reeder (1975) found atmospheres of low $\mathrm{O}_{2}$ and high $\mathrm{CO}$, to be effective in reducing CI in avocados ( Persea americana Mill.).

We do not know why Flavorseal did not reduce the permeability of the fruit surfaces to noncondensable gases as well as the other surface treatments. Coatings are known to differ substantially in their permeability to noncondensable gases and water vapor (Hagenmaier and Shaw, 1992). The amount of solids of squalane, squalene, and safflower oil applied to grapefruit averaged $15 \mathrm{mg} /$ $100 \mathrm{~cm}$ ? and that of Flavorseal averaged $19 \mathrm{mg} / 100 \mathrm{~cm}^{2}$. This small difference suggests that it is the form that the material takes on the fruit surface and not the quantity of material per unit of fruit area that affects the permeability of fruit peels.

In summary, temperature conditioning appears to act in reducing CI on grapefruit by restricting moisture loss, while squalene acts to reduce $\mathrm{CI}$ in another manner. Safflower oil and the terpenes squalane and squalene were found to be effective barriers to gas exchange when applied to grapefruit. These coatings may work in this manner to reduce CI, and all may be used on grapefruit.

\section{Literature Cited}

Albrigo, LG. 1972. Distribution of stomata and epicuticular wax on oranges as related to stem end rind breakdown and water loss. J. Amer. Soc. Hort. Sci. 97:220-223.

Aljuburi, H.J. 1982. Alleviation of chilling injury, and its mechanisms to 'Marsh' and 'Redblush' grapefruit (Citrus paradisi Macf.). PhD. Diss., Univ. of Aritona, Tucson.

Barmore, C.R. and R.H. Biggs. 1972. Ethylene diffusion through citrus leaf and fruit tissue. J. Amer. Soc. Hort. Sci. 97:24-27.

Ben-Yehoshua, S. 1967. Some physiological effects of various skin coatings on orange fruit. Israel J. Agr. Res. 17:17-27.

Ben-Yehoshua, S. 1969. Gasexchange, transpiration, and thecommercial deterioration in storage of orange fruit. J. Amer. Soc. Hort. Sci. 94:524528.

Ben-Yehoshua, S., S.P Burg, and R. Young. 1985. Resistance of citrus fruit to mass transport of water vapor and other gases. Plant Physiol. 79:1048-1053.

Beyer, E.M. and P.W. Morgan. 1970. A method for determining the concentration of ethylene in the gas phase of vegetative plant tissue. Plant Physiol. 46:352-354.

Cameron, A.C. and SF. Yang. 1982. A simple method for the determination of resistance to gas diffusion in plant organs. Plant Physiol. 70:21-23. Chace, W.G., Jr., P.L. Ilarding, J.J. Smoot, and R.H. Cubbedge. 1966. 
Factors affecting the quality of grapefruit exported from Florida. U.S. Dept. Agr. Res. Serv. Mktg. Res. Rpt. 739.

Davis, P.L., W.G. Chace, Jr., and R.H. Cubbedge. 1967. Factors affecting internal oxygen and carbon dioxide concentration of citrus fruits. HortScience 2:168-169.

Eaks, I.L. and W.A. Ludi. 1960. Effects of temperature, washing. and waxing on the composition of the internal atmosphere of orange fruit Proc. Amer. Soc. Hort. Sci. 76:220-228.

Forney, C.F. and W.J. Lipton. 1990. Influence of controlled atmospheres and packaging on chilling sensitivity, p. 257-267. In: C.Y. Wang (ed.). Chilling injury of horticultural crops. CRC Press, Boca Raton, Fla.

Grierson, W. 1974. Chilling injury in tropical and subtropical fruit: Effect of harvest date, degreening, delayed storage and peel color on chilling injury of grapefruit. Proc. Trop. Reg., Amer. Soc. Hort. Sci. 18:66-73.

Hagenmaier, R.D. and P.E. Shaw. 1992. Gas permeability of fruit coating waxes. J. Amer. Soc. Hort. Sci. 117:105-109.

Kramer, G.F. and C.Y. Wang. 1990. Effects of chilling and temperature preconditioning on the activity of polyamine biosynthetic enzymes in Zucchini squash. J. Plant Physiol. 136: 115-119.

McCollum, T.G. and R.E. McDonald. 1992. Electrolyte leakage. respiration, and ethylene production as indices of chilling injury in grapefruit. HortScience 26:1191-1192.

McCollum, T.G., R.E. McDonald, and G.W. Elmstrom. 1991. Temperature conditioning inhibits chilling injury in summer squash ( Cucurbita pepo ) fruit. Proc. Fla. State Hort. Soc. 104:99-101.

McDonald, R.E. 1986. Effects of vegetable oils, $\mathrm{CO}_{2}$, and film wrapping on chilling injury and decay of lemons. HortScience 21:476-477.

Mencarelli, F. 1987. Effect of high $\mathrm{CO}_{2}$ atmospheres on stored Zucchini squash. J. Amer. Soc. Hort. Sci. 112:985-988.

Mencarelli, F., W.J. Lipton, and S.J. Peterson. 1983. Responses of 'Zucchini' squash to storage in low- $\mathrm{O}_{2}$ atmospheres at chilling and nonchilling temperatures. J. Amer. Soc. Hort. Sci. 108:884-890.
Morris, L.L. and H. Platenius. 1939. Low-temperature injury to certain vegetables after harvest. Proc. Amer. Soc. Hort. Sci. 36:609-613.

Nordby, H.E. and R.E. McDonald. 1990a. Method for protecting citrus fruit from chilling injury, and fruit protected thereby. U.S. Patent no. 4921715, 1 May 1990.

Nordby, H.E. and R.E. McDonald. 1990b. Squalene in grapefruit wax as a possible natural protectant against chilling injury. Lipids 25:807-810.

Nordby, H.E. and R.E. McDonald. 1991. Relationship of epicuticular wax composition of grapefruit to chilling injury. J. Agr. Food Chem. 39:957962.

Pantastico, E.B., J. Soule, and W. Grierson. 1968. Chilling injury in tropical and subtropical fruits: II. Limes and grapefruit. Proc. Trop Reg., Amer. Soc. Hort. Sci. 12:171-183.

Purvis, A.C. 1984. Importance of water loss in the chilling injury of grapefruit stored at low temperature. Sci. Hort. 23:261-267.

Saltveit, M.E. and D.R. Dilley. 1977. Simple procedure for preparing dilute concentrations of ethylene in air or oxygen in high pressure cylinders. HortSciencc 12:252-253.

SAS Institute. 1988. SAS/STAT user's guide, release 6.03 edition. SAS Institute, Cary, N.C.

Schulman, Y. and S.P. Monselise. 1970. Some studies on the cuticular wax of citrus fruits. J. Hort. Sci. 45:471-478.

Spalding, D.H. and W.F. Reeder. 1975. Low-oxygen high-carbon dioxide controlled atmosphere storage for control of anthracnose and chilling injury of avocados. Phytopathology 65:458-460.

Wang, C.Y. 1982. Physiological and biochemical responses of plants to chilling stress. HortScience 17:173-186.

Wang, C.Y. 1990. Alleviation of chilling injury of horticultural crops, p. 281-302. In: C.Y. Wang (ed.). Chilling injury of horticultural crops. CRC Press, Boca Raton, Fla.

Wang, C.Y. and Z.L. Ji. 1989. Effect of low-oxygen storage on chilling injury and polyamines in Zucchini squash. Sci. Hort. 39:1-7. 